\title{
IMPLEMENTASI PENILAIAN PSIKOMOTOR PADA MATA PELAJARAN PENDIDIKAN AGAMA ISLAM DAN BUDI PEKERTI
}

\author{
Sudiman \\ Guru MTs Negeri Kajai Sei Rotan Pariaman Selatan Kota Pariaman \\ email: sudiman_alharits@yahoo.co.id
}

\begin{abstract}
In this qualitative study, the researcher described the implementation of psychomotor assessment for Islamic Education and Character Subject in State Islamic Secondary School Kajai Sei Rotan South Pariaman. The observation, documentation and interview were used on collecting data. The data were analyzed by applying data reduction, data display and data conclusion. The result showed that the psychomotor assessment had used the principles of assessment but was not perfect because of limited time, limited teacher, and limited teachers' knowledge.
\end{abstract}

Kata Kunci: Psychomotor Assessment, Islamic Education and Character Subject, State Islamic Secondary School, Kajai South Pariaman

\section{PENDAHULUAN}

Perbaikan pendidikan berbasis standar (standard-based reform) dan pengembangan pengajaran berbasis kompetensi (competencebased instruction) telah dijadikan landasan bagi banyak negara dalam meningkatkan kualitas pendidikannya. Di Amerika Serikat gagasan tentang reformasi pendidikan berbasis standar muncul sejak diterbitkannya A Nation at Risk tahun 1983 (Chatterji, 2002). Kemudian melalui No Child Left Behind Act 2001 ditetapkan adanya minimum competence test (MTC) untuk mata pelajaran Matematika dan Membaca (Kupper, 2006). MTC ini menjadi standar minimal yang harus dicapai oleh siswa ketika akan naik tingkat.

Pembelajaran berbasis standar kompetensi juga dikembangkan di beberapa negara lain. Di Inggris (UK), dimulai dengan penerapan model penilaian berbasis kompetensi (comptence-based assessment) di tahun 1970-an (Purcell, 2001). Faktor pemicu kebijakan ini di antaranya adalah meningkatnya jumlah pengangguran dan angkatan kerja kurang terdidik untuk bekerja. Oleh karena itu pada tahun 1997 dibentuk National Council for Vocational Qualifications (NCVQs) sebagai bagian dari Qualifications and Curriculum Authority 
dan sebagai badan (super-body) baru yang bertanggung jawab untuk semua kualifikasi non-universitas untuk mendukung kebijakan di bidang pendidikan kejuruan (Wolf, 1998).

Pada tahun 1997, Belanda telah membentuk Educational Development and Assessment System (EDAS) untuk mengimplementasikan pembelajaran berbasis standar kompetensi. EDAS merupakan sistem yang dirancang untuk menghubungkan antara kurikulum berbasis kompetensi dengan pendekatan baru dalam penilaian untuk mencapai kesesuaian yang lebih baik antara tujuan pembelajaran dan tujuan kompetensi yang ingin dicapai (Tillema, dkk 2000). Kesesuaian ini diyakini akan memperbaiki kualitas lulusan.

Pemerintah melalui Depdiknas telah berusaha meningkatkan kualitas pendidikan namun hasilnya belum berubah secara signifikan. Rendahnya kualitas pendidikan ini dapat dilihat dari hasil Studi The Third Internasional Mathematics and Science Study (TIMSS) tahun 1999, Indonesia pada urutan ke-32 untuk IPA dan ke-34 untuk Matematika dari 38 negara peserta. Di Asia Tenggara, kedua bidang studi tersebut, Indonesia berada di bawah Malaysia dan Thailand, sedikit di atas Filipina. Bahkan hasil survey The Political and Economic Risk Consultancy (PERC) menunjukkan bahwa sistem pendidikan di Indonesia berada pada peringkat terakhir dari 12 negara, dan berada di bawah Vietnam yang menempati peringkat ke-11. Untuk itu diperlukan upaya sinergisme dengan penuh komitmen pada semua pihak yang terlibat dalam bidang pendidikan dalam upaya meningkatkan kualitas pendidikan di Indonesia (Hayat dan Sutarsyah, 2003).

Permasalahan peningkatan kualitas pendidikan pada dasarnya terletak pada pengelola pendidikan untuk melakukan inovasi atau pembaharuan. Inovasi dapat berarti perubahan ke arah yang lebih baik. Jadi untuk meningkatkan kualitas pendidikan para pengelola harus memiliki semangat untuk melakukan perubahan- perubahan secara terus-menerus dan berkelanjutan sesuai dengan tuntutan masyarakat dan perkembangan ilmu pengetahuan, teknologi serta seni.

Penerapan kompetensi menuntut perubahan paradigma dalam pembelajaran karena tidak hanya menyebabkan perubahan konsep, metode, dan strategi guru dalam mengajar tetapi pada gilirannya menuntut perubahan dalam sistem penilaian. Sistem penilaian hasil belajar yang digunakan adalah model penilaian otentik. Penilaian berbasis kompetensi ini mencakup tiga aspek kemampuan yaitu kemampuan berpikir (kognitif), psikomotor dan kepribadian 
(afektif) yang pelaksanaannya dilakukan secara parsial sesuai dengan prosedur dan mekanismenya. Penilaian sendiri mengandung makna tentang penafsiran hasil pengukuran dan penentuan hasil belajar.

Dalam kurikulum 2013 yang tengah diterapkan di Indonesia penilaian otentik (assessment authentic) sedang menjadi trend karena dianggap benar-benar asli dari hasil belajar peserta didik. Menurut Daryanto (2013) Penilaian otentik (assessment authentic) adalah pengukuran yang bermakna secara signifikan atas hasil belajar peserta didik untuk ranah sikap, keterampilan dan pengetahuan.

Penilaian autentik pada Kurikulum 2013 mengacu pada Permendikbud Nomor 66 Tahun 2013 tentang Standar Penilaian Pendidikan dan Permendikbud Nomor 104 Tahun 2014 tentang Penilaian Hasil Belajar oleh Pendidik pada Pendidikan Dasar dan Pendidikan Menengah. Dalam Permendikbud Nomor 66 Tahun 2013 menjelaskan bahwa standar penilaian pendidikan adalah kriteria mengenai mekanisme, prosedur dan instrumen penilaian hasil belajar peserta didik. Penilaian pendidikan sebagai proses pengumpulan dan pengolahan informasi untuk mengukur pencapaian hasil belajar peserta didik mencakup: penilaian autentik, penilaian diri, penilaian berbasis portofolio, ulangan, ulangan harian, ulangan tengah semester, ulangan akhir semester, ujian tingkat kompetensi, ujian mutu tingkat kompetensi, ujian nasional dan ujian. (Permendikbud Nomor 66 Tahun 2013).

Sementara dalam Permendikbud Nomor 104 Tahun 2014 menjelaskan bahwa penilaian dalam proses pendidikan merupakan komponen yang tidak dapat dipisahkan dari komponen lainnya khususnya pembelajaran. Penilaian merupakan proses pengumpulan dan pengolahan informasi untuk mengukur pencapaian hasil belajar peserta didik. Penilaian hasil belajar oleh pendidikan dilakukan untuk memantau proses, kemajuan belajar, dan perbaikan hasil belajar peserta didik secara berkesinambungan. Lebih lanjut, penilaian belajar oleh pendidik memiliki peran antara lain untuk membantu peserta didik mengetahui capaian pembelajaran (learning outcomes). Berdasarkan penilaian hasil belajar oleh pendidik, pendidik dan peserta didik dapat memperoleh informasi tentang kelemahan dan kekuatan pembelajaran (Permendikbud No. 104 Tahun 2014).

Berdasarkan hasil penelitian Puslitbang Kebudayaan terhadap Evaluasi Pendampingan Kurikulum 2013 ratarata pemahaman terhadap penilaian keterampilan $86,09 \%$ atau masuk dalam kategori sangat baik, sedangkan yang belum 
memahami sebesar 13,91\%. Guru yang belum memahami penilaian dikarenakan guru kurang mampu melakukan penilaian kompetensi sikap, pengetahuan dan penilaian keterampilan secara baik disebabkan kurang referensi yang dipahami dan penilaian yang terlalu rumit menyebabkan siswa terbebani karena banyaknya jenis soal dan guru menjadi terlalu sibuk dengan penilaian.

Salah satu kelemahan itu adalah bahwa penilaian untuk mata pelajaran PAI masih didominasi dan berfokus pada penilaian hasil belajar ranah kognitif melalui tes. Tes tersebut hanya mengukur dan mengevaluasi tentang sejauh mana siswa MTs Negeri mampu menguasai sejumlah materi-materi PAI yang terdapat dalam buku ajar. Dengan kata lain, pembelajaran PAI yang demikian jelas lebih menekankan pada penguasaan sejumlah konsep dan kurang menekankan pada penguasaan kemampuan dasar kerja ilmiah atau keterampilan pembelajaran PAI (Hasil Wawancara denga guru PAI MTs Negeri Kajai Sei Rotan, 20 Januari 2016). Padahal, terlepas dari pengusaan konsep, mengembangkan rasa ingin tahu dan berfikir kritis mereka juga penting. Bahkan juga sering kali dalam kegiatan pembelajarannya di sekolah itu, ketika seorang guru melakukan suatu percobaan, guru tidak menilai keterampilan kinerja siswanya. Sebagai gantinya, guru hanya mengevaluasi kognitif siswanya. Itu dibenarkan karena kebanyakan guru tidak mempunyai cukup pengalaman keterampilan dalam mengevaluasi keterampilan kinerja. Dampaknya adalah ketidakmauan guru untuk melakukan penilaian kinerja.

Berdasarkan observasi awal peneliti (20 Januari 2016), Guru PAI masih bingung dalam menerapkan konsep penilaian terutama dalam implementasi penilaian sikap di kurikulum 2013 ini. Dengan adanya kurikulum 2013 seorang guru PAI dituntut memiliki kemampuan dalam merencanakan, melaksanakan, mengevaluasi dan menganalisis. Hasil observasi awal juga menunjukkan masih lemahnya kemampuan Guru dalam melakukan evaluasi dan penilaian, karena banyaknya aspek penilaian yang harus dinilai pada kurikulum 2013. Dari hasil observasi dan wawancara peneliti merasa masalah ini penting untuk diteliti, terkait bagaimana implementasi penilaian psikomotor pada mata pelajaran Pendidikan Agama Islam dan Budi Pekerti di MTs Negeri Kajai Sei Rotan Pariaman Selatan Kota Pariaman.

\section{PENILAIAN PSIKOMOTOR PAI}

Penilaian (assessment) menurut Kamus Besar Bahasa Indonesia (KBBI) berasal dari kata nilai yang berarti kepandaian, biji dan ponten. Sedangkan Penilaian 
yaitu proses, cara, perbuatan menilai, pemberian nilai (biji, kadar mutu, harga). Penilaian dapat diartikan sebagai proses untuk mendapatkan informasi dalam bentuk apapun yang dapat digunakan untuk dasar pengambilan keputusan tentang siswa, baik yang menyangkut kurikulum, program belajar, iklim sekolah maupun kebijakankebijakan sekolah (KBBI, 2002).

\section{Dalam kitab Ruhuttarbiyah Watta'lim} (Athiyah, 1950) dikatakan sebagai berikut "evaluasi atau penilaian adalah ujian yang dilakukan oleh sekolah untuk mengetahui kadar kemampuan siswa terhadap materi yang telah mereka pelajari dan untuk mengetahui kelemahan siswa (mendiagnosis), bisa berbentuk lisan, tulisan dan perbuatan". Lebih lanjut Gravells (2009) mengatakan "assessment is a way of finding out if learning has taken place. It enables you, the assessor, to ascertain if your learner has gained the required skills and knowledge needed at a given point towards their programme or qualification". Menurut Brown (2010) assessment is a method used to measure the ability, knowledge or performance of a person. Brown (2010) menambahkan bahwa "assessment is an ongoing process that encompasses a much wider domain".

Penilaian adalah suatu prosedur sistematis dan mencakup kegiatan mengumpulkan, menganalisis serta menginterpretasikan informasi yang dapat digunakan untuk membuat kesimpulan tentang karakteristik seseorang atau objek. Secara khusus untuk dunia pendidikan, Gronlund Linn mendefinisikan penilaian sebagai suatu proses yang sistematis dan mencakup kegiatan mengumpulkan, menganalisis, seta menginterpretasikan informasi untuk menentukan seberapa jauh seorang siswa atau sekelompok siswa mencapai tujuan pembelajaran yang telah ditetapkan, baik aspek pengetahuan, sikap maupun keterampilan.

Hasil belajar psikomotor terbagi menjadi tiga, yaitu specific responding, motor chaining, rule using. Pada tingkat specific responding peserta didik mampu merespons hal-hal yang sifatnya fisik, (yang dapat didengar, dilihat, atau diraba), atau melakukan keterampilan yang sifatnya tunggal, misalnya memegang raket, memegang bed untuk tenis meja. Pada motor chaining peserta didik sudah mampu menggabungkan lebih dari dua keterampilan dasar menjadi satu keterampilan gabungan, misalnya memukul bola, menggergaji, menggunakan jangka sorong, dll. Pada tingkat rule using peserta didik sudah dapat menggunakan pengalamannya untuk melakukan keterampilan yang komplek, misalnya bagaimana memukul bola secara tepat agar dengan tenaga yang sama hasilnya lebih baik. Hasil belajar psikomotor dapat 
dibedakan menjadi lima tahap, yaitu: imitasi, manipulasi, presisi, artikulasi, dan naturalisasi. Imitasi adalah kemampuan melakukan kegiatan-kegiatan sederhana dan sama persis dengan yang dilihat atau diperhatikan sebelumnya.

Keterampilan psikomotorik berhubungan dengan anggota tubuh atau tindakan yang memerlukan koordinasi antara syaraf dan otak. Jika dilihat dari sistem taksonomi/sistem klasifikasi ranah psikomotor ada 6, yaitu (1) reflex movements yang terdiri dari segmental reflexes, intersegmental reflexes, suprasegmental reflexes; (2) basic-fundamental mevements yang terdiri dari locomotor movement, nonlocomotor movement dan manipulative movement; (3) perceptual abilitéis yang terdiri dari kinesthetic discrimination, visual discrimination, auditory discrimination, tactile discrimination dan coordinated discrimination; (4) physical abilitéis yang terdiri dari endurance, strength, flexibility, dan agility; (5) skilled movements yang terdiri dari simple adaptive skill, compound adaptive skill dan complex adaptive skill; (6) nondiscursive movement yang terdiri dari expressive dan interpretive movement.

Definisi lain mengatakan bahwa yang dimaksud dengan kategori kemampuan psikomotorik adalah kemampuan yang menyangkut kegiatan otot dan kegiatan fisik. Jadi tekanan kemampuan yang menyangkut penguasan tubuh dan gerak. Penguasaan kemampuan ini meliputi gerakan anggota tubuh yang memerlukan koordinasi syarat otot yang sederhana dan bersifat kasar menuju gerakan yang menurut koordinasi syarat otot yang lebih kompleks dan bersifat lancar.

Penilaian aspek psikomotorik juga termasuk dalam penilaian keterampilan yaitu penilaian terhadap kecakapan siswa dalam melakukan sesuatu, sesuai dengan tuntutan tujuan pembelajaranya. Dalam hal ini adalah kemampuan siswa dalam penguasaan menggerakan anggota tubuh atau pada kegiatan fisik. Adapun bentuk tes yang digunakan untuk mengukur aspek psikomotorik yaitu tes tindakan atau perbuatan atau Performance Assessment yaitu suatu penilaian yang meminta peserta tes untuk mendemonstrasikan dan mengaplikasikan pengetahuan kedalam berbagai macam konteks sesuai dengan kriteria yang diinginkan. Kriteria-kriteria yang diinginkan berhubungan dengan keterampilan dan pengetahuan yang diperlukan dalam praktek kehidupan seharihari atau dikenal dengan nama Autentic Assessment. Psikomotorik merupakan salah satu aspek dari kemampuan peserta didik yang harus diukur dan dinilai perkembangannya selain aspek pengetahuan (kognitif) dan penanaman nilai (afektif). Hal ini dilakukan selama proses kegiatan belajar mengajar 
dengan mengamati aktifitas peserta didik sebagaimana yang terjadi. Peserta tes diminta untuk mendemonstrasikan kemampuannya dalam mengkreasikan suatu produk atau terlibat dalam suatu aktivitas perbuatan. Produk dari Performance Assessment lebih penting daripada perbuatan (performance)nya. Penilaian kinerja memiliki kelebihan dapat mengungkapkan potensi siswa dalam memecahkan masalah, penalaran, dan komunikasi dalam bentuk tulisan maupun lisan.

Berdasarkan uraian tentang penilaian, dan aspek psikomotorik dapat diambil kesimpulan bahwa yang dimaksud dengan penilaian aspek psikomotorik adalah pengumpulan dan penggunaan informasi tentang hasil belajar peserta didik dengan tinjauan terhadap kemampuan dalam melakukan atau mempraktikkan suatu perbuatan yang berdasarkan potret atau profil kemampuanya. Hal ini sesuai dengan daftar kompetensi yang ditetapkan oleh kurikulum. Kemudian penerapan pada pendidikan agama Islam penilaian aspek psikomotorik berorientasi pada keterampilan motorik atau kemampuan mempraktikkan ajaran agama seperti wudlu, sholat, baca tulis al Qur'an dan sebagainya. Penilaian psikomotorik Pendidikan Agama Islam biasanya berupa pemberian kegiatan tertentu yang harus dikerjakan oleh siswa baik secara individual atau kelompok dan ini dilakukan selama berlangsungnya proses kegiatan belajar mengajar

\section{METODE PENELITIAN}

Pendekatan penelitian yang dilakukan dalam penelitian ini adalah pendekatan penelitian kualitatif yang bermaksud untuk menggali data dari subjek sacara holistic (untuh). Data yang dihasilkan berupa katakata tertulis atau lisan dari orang atau prilaku yang diamati (Moleong, 2006). Penelitian ini bertujuan untuk mendeskripsikan tentang proses penilaian psikomotor terhadap mata pelajaran PAI di MTs Negeri Kajai Sei Rotan.

Dalam penelitian ini teknik pengumpulan data yang digunakan oleh peneliti adalah dengan wawancara terstruktur agar informasi yang didapat lebih terbuka, pengamatan dokumen berupa RRP mata pelajaran PAI yang memuat penilaian psikomor, dan obsevasi terhadap pelaksanaan penilaian psikomotor pada mata pelajaran PAI (Moleong, 2006).

Miles dan Huberman (1994) menyebutkan tiga tahap dalam pengumpulan data yaitu reduksi data yaitu proses pemilihan dan pemusatan perhatian yang muncul dari catatan kasar, penyajian data (data display) yaitu penyajian data kualitatif dalam bentuk uraian singkat, matris, grifis dan tabel, dan 
penarikan kesimpulan atau verifikasi yang bersifat terbuka dan akan berubah jika tidak ditemukan data pendukung di lapangan.

\section{HASILPENELITIAN DAN PEMBAHASAN}

MTs Negeri Kajai Sei Rotan dalam penilaian psikomotorik teknik yang digunakan adalah pendengaran untuk menilai keterampilan membaca atau menghafal dan pengamatan atau observasi untuk menilai keterampilan memperagakan gerakan seperti penilain terhadap praktik sholat jenazah. Hasilnya kemudian dimasukkan ke dalam blanko penilaian. Proses penilaian yang dilakukan oleh guru atas kemampuan praktik siswa hanya secara sekilas, karena waktu yang digunakan untuk menilai satu siswa rata-rata hanya lima menit. Ditambah lagi blangko sebagai pedoman penilaian hanya memuat indikator yang sifatnya masih global. Sedangkan karakteristik secara detail hanya sebatas gambaran sekilas tidak ditulis dalam lembar pedoman penilaian (Hasil Wawancara Guru PAI H. Afrinaldi, Lc. Tanggal 9 Februari 2016).

Teknik pengamatan tersebut sebenarnya belum cukup untuk mendapatkan data yang valid. Secara ideal bahwa kriteria untuk mengukur keterampilan siswa harus dilakukan sekurang-kurangnya tiga puluh menit. Kurang dari waktu tersebut diperkirakan para penilai belum dapat menangkap gambaran tentang pola keterampilan yang mencerminkan kemampuan siswa. Akan tetapi jika menengok jumlah dalam satu kelas mencapai tiga puluh siswa maka idealisme seperti itu sangat sulit untuk diterapkan. Selain itu juga, guru seharusnya menentukan pedoman secara tertulis seberapa jauh suatu keterampilan tertentu harus dibagi-bagi menjadi tindakan-tindakan yang lebih kecil yang menjadi sentral dalam pengukuran. Sehingga tujuan atau target yang harus dikuasai oleh siswa bisa menjadi jelas.

Pada praktiknya di MTs Negeri Kajai Sei Rotan hanya sebagaian guru yang sudah menggunakan pedoman tertulis yang berisi beberapa indikator dari suatu keterampilan tertentu. Namun guru masih mendapatkan masalah waktu dan tenaga. Tugas yang begitu banyak dan masalah administrasi yang rumit serta adanya kesibukan lain membuat guru belum mampu untuk melaksanakan penilaian secara optimal (Hasil Wawancara Guru PAI H. Afrinaldi, Lc. Tanggal 9 Februari 2016).

Sistem penilaian yang digunakan di MTs Negeri Sei Rotan memakai standar umum yaitu berupa kualitatif (huruf) dan kuantitatif (angka). Memang tidak ada keharusan memakai sistem tertentu, guru bisa memilih di antara teknik penyekoran sesuai dengan keinginan. Dalam hal ini 
yang menjadi sorotan peneliti bukan pada penyajian hasil nilai akhir akan tetapi lebih pada proses pemberian nilai. Sebagaimana diketahui bahwa metode yang dipakai guru Pendidikan Agama Islam yaitu pengamatan sekilas, kemudian ditetapkan hasilnya. Tentunya data dari hasil penilaian dengan cara semacam itu kurang obyektif, seharusnya guru menggunakan pedoman tertulis yang berisi aspek-aspek kemampuan yang jelas. Kemudian prosedur untuk menentukan nilai akhir dari suatu keterampilan dengan menjumlahkan hasil nilai seluruh indikatornya serta membagi dengan skor maksimum kemudian dikalikan seratus.

Berdasarkan data di lapangan ternyata ada guru yang sudah memakai teknik sebagaimana yang telah dijelaskan dalam teori di muka walaupun masih ada sisi kelemahan apa yang dilakukan oleh guru tersebut, yaitu penentuan skor untuk setiap indikator kurang dijelaskan secara spesifik. Namun demikian peneliti menilai langkah tersebut sudah cukup baik.

Nilai yang diberikan oleh guru berdasarkan dokumen yang ada adalah ratarata $\mathrm{A}$ atau 8. Hal tersebut menunjukkan bahwa tingkat kemampuan siswa MTs Negeri Kajai Sei Rotan dalam keterampilan motorik sangat baik (Studi Dokumentasi Rekapitulasi Nilai Guru PAI, 2 Februari
2016). Kenyataan itu wajar saja, karena memang selama ini dari guru dalam menjalankan tugas mengajar dilakukan dengan sungguh-sungguh serta adanya dukungan dari pihak sekolah. Pernyataan peneliti seperti itu didasari dua hal yaitu 1) selama ini alokasi waktu yang diberikan untuk mata pelajaran Pendidikan Agama Islam sebanyak enam jam atau tiga kali tatap muka dalam satu minggu. Jika diamati ratarata di lembaga pendidikan umum porsi waktu untuk mata pelajaran Pendidikan Agama Islam hanya dua jam atau satu kali tatap muka; dan 2) adanya peraturan yang mewajibkan seluruh siswa untuk mengikuti kegiatan ekstra pendalaman ilmu agama Islam, yang dilaksanakan di luar jam pelajaran efektif.

Kemudian sistem pelaporan hasil penilaian yang diterapkan di MTs Negeri Kajai Sei Rotan untuk kelas 1 (satu) sampai kelas 3 (tiga) yaitu memakai sistem tiga bulan sekali. Bentuk pelaporan berupa Lembar Perkembangan Murid yang memuat beberapa indikator yang harus dikuasai oleh siswa selama satu semester. Penyajian laporan secara tertulis tersebut diberikan kepada Kepala Sekolah kemudian diteruskan kepada wali murid. Hal ini merupakan salah satu langkah yang baik dan maju. Tentunya dengan strategi seperti itu perkembangan siswa akan lebih terperhatikan dan bisa 
mengurangi penumpukkan masalah. Dari segi positif yang lainnya komunikasi antara pihak sekolah dengan wali murid akan terus bisa terjaga.

Berdasarkan hasil penelitian bahwa implementasi penilaian psikomotorik di MTs Negeri Kajai Sei Rotan belum 100\% sesuai dengan konsep yang ada. Namun berdasarkan interview, peneliti melihat bahwa dari guru Pendidikan Agama Islam sudah berusaha untuk mengimplementasikan penilaian psikomotorik secara sungguhsungguh (Hasil Wawancara Guru PAI H. Afrinaldi, Lc. Tanggal 9 Februari 2016).

Kendala yang dihadapi guru dalam penilaian psikomotor di MTs Negeri Kajai Sei Rotan yaitu selain tugas guru melakukan penilaian mereka juga harus mempersiapkan dan menyampaikan meteri pada siswa. Bila dikupas tugas guru di atas membutuhkan banyak waktu, tenaga, dan pikiran.

Sebelum melakukan penilaian seorang guru harus melakukan persiapan yang membutuhkan waktu tersendiri dalam merencanakan apa yang akan dilakukan. Persiapan yang dilakukan oleh guru meliputi persiapan pribadi (materi dan emosi) dan persiapan tertulis (satpel), begitu juga dengan penyampaian materi. Apalagi mengevaluasi kemampuan psikomotorik siswa merupakan pekerjaan tersendiri yang membutuhkan waktu, tenaga, dan pikiran yang cukup banyak. Bahkan bisa dikatakan melebihi yang dibutuhkan untuk menyampaikan materi. Seperti pembuatan alat ukur penilaian sebagai lembar pedoman pengamatan.

Waktu merupakan masalah klasik yang menjadi hambatan para guru Pendidikan Agama Islam dalam melaksanakan tugas mengajar. Walaupun di MTs Negeri Kajai Sei Rotan kebijakan untuk alokasi waktu yang diberikan untuk Pendidikan Agama Islam sudah enam jam dalam satu minggu ternyata menurut sebagian guru masih dirasa kurang. Ternyata waktu enam jam tersebut masih belum sebanding dengan materi dan tugas lain yang harus dijalankan oleh guru.

Berkaitan dengan pelaksanaan penilaian pada aspek psikomotorik di mana secara ideal untuk menilai satu siswa membutuhkan waktu 30 menit. Tentunya hal itu sangat tidak mungkin untuk dilaksanakan karena waktu yang ada tidak digunakan untuk melakukan penilaian satu ranah saja.

Untuk setiap kelas rata-rata ada 30 siswa padahal idealnya hanya 10-20. Tentunya hal ini merupakan catatan tersendiri dalam proses penilaian psikomotorik. Mengingat tuntutan penilaiannya adalah satu persatu siswa harus memperagakan secara langsung keterampilan yang dikuasainya. Dengan jumlah seperti itu proses pengambilan nilai tentunya akan kurang maksimal. 
Kegiatan guru setelah melakukan proses pembelajaran sebagai perwujudan dari tuntutan adanya standar proses pendidikan adalah melakukan penilaian hasil belajar. Penilaian hasil belajar secara esensial bertujuan untuk mengukur keberhasilan pembelajaran yang dilakukan oleh guru dan sekaligus mengukur keberhasilan peserta didik dalam penguasaan kompetensi yang telah ditentukan. Dengan demikian, penilaian hasil belajar itu sesuatu yang sangat penting.

Dengan penilaian, guru bisa melakukan refleksi dan evaluasi terhadap kualitas pembelajaran yang telah dilakukan. Apakah metode, strategi, media, model pembelajaran dan hal lain yang dilakukan dalam proses pembelajaran itu tepat dan efektif atau sebaliknya. Jika hasil belajar peserta didik dalam ulangan harian atau formatif masih di bawah Kriteria Ketuntatasan Minimal (KKM), maka bisa dikatakan proses pembelajaran yang dilkakukan oleh guru kurang berhasil. Jika hasil belajar peserta didik di atas KKM, maka bisa dikatakan proses pembelajaran yang dilakukan oleh guru berhasil.

Berdasarkan pengamatan langsung yang dilakukan oleh peneliti dapat ditegaskan bahwa kegiatan pembelajaran yang dilakukan guru PAI di MTs Negeri Kajai Sei Rotan cukup dinamis dengan mampu menciptakan suasana pembelajaran yang kondusif, termasuk pada kegiatan penilaian yang dilakukan, nampak dilakukan dengan berorientasi pada ketercapaian kompetensi peserta didik tidak hanya pada ranah kognitif saja, tetapi juga pada ranah afektif dan psikomotor. Instrumen penilaian psikomotor ada dua hal yang perlu diperhatikan, yaitu membuat soal dan membuat instrumen untuk mengamati jawaban peserta didik. Soal untuk hasil belajar ranah psikomotor dapat berupa soal, lembar kerja, lembar tugas, perintah kerja, dan lembar eksperimen. Untuk instrumen mengamati jawaban siswa dapat berupa lembar observasi, lembar penilaian, dan portofolio yang digunakan adalah tes, pengamatan, dan penugasan. Perencanaan pembelajaran yang dilakukan oleh guru PAI di MTs Negeri Kajai Sei Rotan adalah meliputi menyusun silabus dan membuat rencana pelaksanaan pembelajaran yang memuat identitas mata pelajaran, kompetensi inti, kompetensi dasar, indikator pencapaian kompetensi, tujuan pembelajaran, materi pokok, alokasi waktu, metode pembelajaran, kegiatan pembelajaran, penilaian hasil belajar, dan sumber belajar (Studi Dokumentasi RPP Guru PAI, 2 Februari 2016).

Sebenarnya keberhasilan guru dalam proses pembelajaran sebagaimana dikatakan oleh (Suyanto dkk, 2013) yaitu berusaha tampil di depan kelas dengan prima, bijaksana, ceria di dalam kelas, berusaha 
mengendalikan emosi, menjawab semua pertanyaan murid, memiliki rasa malu dan takut, tidak sombong dan berlaku adil. Dalam penerapan penilaian autentik ada beberapa faktor pendukung yang menguatkan untuk bagaimana kegiatan penilaian dimaksud dapat berjalan dengan sebaik-baiknya. Sebagaimana dikatakan oleh beberapa informan: Ketika penerapan penilaian psikomotor pada mata pelajaran PAI dilakukan, ada beberapa faktor yang mendukung kegiatan penilaian itu, sehingga bisa dilaksanakan dengan sebaik-baiknya, yaitu; (1) kompetensi yang dimiliki oleh guru, (2) kesiapan peserta didik, (3) pola kepemimpinan kepala sekolah, (4) terwujudnya lingkungan belajar yang kondusif, (5) adanya laboratorium ibadah, dan (6) adanya kegiatan ekstra kurikuler. Faktor-faktor inilah yang mendukung pada pelaksanaan kegiatan penilaian kompetensi psikomotorik (Hasil Wawancara Guru PAI H. Afrinaldi, Lc. Tanggal 9 Februari 2016).

Kegiatan pembelajaran yang dilakukan oleh guru haruslah dapat mewujudkan pembelajaran yang interaktif, inspiratif, menyenangkan, menantang, memotivasi peserta didik untuk berpartisipasi aktif, serta memberikan ruang yang cukup bagi prakarsa, kreativitas, dan kemandirian sesuai dengan bakat, minat, dan perkembangan fisik serta psikologis peserta didik. Hal ini menunjukkan bahwa pembelajaran yang didesain oleh guru harus berorientasi pada aktivitas peserta didik (Wina, 2014).

\section{KESIMPULAN}

Pelaksanaan penilaian aspek psikomotorik Pendidikan Agama Islam di MTs Negeri Kajai Sei Rotan berdasarkan dari hasil penelitian dengan berlandaskan teori, peneliti dapat mengambil kesimpulan secara umum sudah memegang prinsip-prinsip penilaian walaupun masih kurang sempurna. Kenyataan tersebut dikarenakan ada beberapa kendala yang dihadapi di antaranya minimnya alokasi waktu, keterbatasan tenaga guru, dan kurangnya pengetahuan guru.

\section{KEPUSTAKAAN ACUAN}

Brown, H. Douglas. (2010). Language Assessment Principles in Classroom Practice: Second edition. New York: Longman.

Gravells, Ann. (2009). Principles and Practice of Assessment in the Life Long Learning Sector. Inggris: Learning Matters.

Hayat, Bahrul dan Sutarsyah, Cucu. (2003). Prinsip dan Strategi Penilaian Tingkat Kelas. Jakarta: Pusat Penilaian Pendidikan Departemen Pendidikan Nasional.

Chatterji, M. (2002). "Models and methods for Examining Standards-Based Reforms 
and Accountability Initiatives: Have the Tools of Inquiry Answered Pressing Questions on Improving Schools?" Review of Educational Research, 72, 3, p.345-38

Kamus Besar Bahasa Indonesia. (2002). Jakarta: Balai Pustaka Departemen Pendidikan Nasional Edisi ke-3.

Miles, Mathew B \& Huberman, A. Michael. (1994). Qualitative Data Analysis. An Expanded Sourcebook Second Edition. Thousand Oaks, CA: Sage.

Moleong, Lexi J. (2006). Metodologi Penelitian Kualitatif. Bandung: Rosdakarya.

Kuper, D.B. (2006). "Reconsidering the Minimum Competency Test Strategy in No Child Left Behind: An Agenda Reform”. Practical Assessment, Research \& Evaluation, 11, 1. Diambil pada 21 Nopember 2006, dari http://proquest. umi.com/pqdweb.

Athiyah, Muhammad Al-Abrasy. (1950). Rubuttarbiyah Wattalim. Beirut: Darul Iliya.

Permendikbud Nomor 66 Tahun 2013
Permendikbud Nomor 104 Tahun 2014

Purcell, J. (2001). "Case study: National Vocational Qualifications and Competence- Based Assessment for Technicians From Sound Principles to Dogma”. Education and Training, 43, 1, 30-39. Diambil pada 10 Desember 2006 dari $h t t p: / / p r o q u e s t . u m i . c o m / p q d w e b$

Wina, Sanjaya. (2014). Strategi Pembelajaran (Berorientasi Standar Proses Pendidikan. Jakarta: Esensi.

Tillema H. H, Kessels, J. W. M., \& Meijers, F. (2000). "Competencies as Building Blocks for Integrating Assessment with Instruction in Vocational Education: a Case from the Netherlands". Assessment \& Evaluation in Higher education, Vol.3, No.3, 265-278, Diambil pada 28 Mei 2008, dari http://proquest.umi.com/ pqdweb

Wolf, A. (1998). "Portofolio Assessment as National Policy: The National Council for Vocational Qualivications and its Quest for a Pedagogical Revolution”. Education and Training, 5, 3, 413-445. Diambil pada 3 April 2008, dari http:// proquest.umi.com/pqdweb. 